\title{
HYDROCLIMATIC AND GEOLOGICAL CONDITIONS OF THE VARIABILITY OF FLUVIAL TRANSPORT RATE IN THE UPPER PART OF THE WIEPRZ RIVER CATCHMENT
}

\author{
Andrzej Świeca, Waldemar Kociuba, Teresa BrzezińsKa-Wójcik \\ Faculty of Earth Sciences and Spatial Management, Maria Curie-Skłodowska University, Poland
}

Manuscript received: July 26, 2014

Revised version: January 11, 2015

\begin{abstract}
Świeca A., Kociuba W., BrZezińSKA-WójciK T., 2015. Hydroclimatic and geological conditions of the variability of fluvial transport rate in the upper part of the Wieprz river catchment. Quaestiones Geographicae 34(1), Bogucki Wydawnictwo Naukowe, Poznań, pp. 5-14, 2 tables, 2 figs. DOI 10.1515/quageo-2015-0001, ISSN 0137-478X.

ABSTRACT: The article summarises the results of observations conducted in the periods 1989-1992, 1998-2000, and 20012003 in the catchment of the Roztocze section of the Wieprz River with an area of $404 \mathrm{~km}^{2}$. The presented results of the study on fluvial transport document the response of an upland river to variable hydro-climatic conditions. Fluvial transport rate in periods extreme in hydrological terms was compared. In the conditions of low water stages (19891992) and mean annual discharges lower than the mean multiannual by $19 \%$, the Wieprz River discharged an average of 13300 tonnes of solutions and 485 tonnes of suspensions annually. The unitary indices amounted to 32.7 and $1.2 \mathrm{t} /$ $\mathrm{km}^{2} /$ year, respectively. In the years 1998-2000, in the conditions of high water stages and mean annual discharges higher than the multiannual by $41 \%$, the Wieprz River discharged approximately 22,800 tonnes of solutions and 981 tonnes of suspensions annually. The unitary indices increased proportionately to $56.2 \mathrm{t} / \mathrm{km}^{2} /$ year and $2.4 \mathrm{t} / \mathrm{km}^{2} /$ year, respectively. In the years 2001-2003, in the conditions of variable water stages and discharges higher than the multiannual by $12 \%$, the Wieprz River discharged an average of approximately 17,500 tonnes of solutions and 441 tonnes of suspensions annually. The unitary indices reached the values of $43.3 \mathrm{t} / \mathrm{km}^{2} /$ year and $1.1 \mathrm{t} / \mathrm{km}^{2} /$ year, respectively.
\end{abstract}

KEY WORDS: hydro-climatic drivers, geological conditions, fluvial transport, Wieprz River catchment, Roztocze Region

Address of the corresponding author: Andrzej Świeca, Faculty of Earth Sciences and Spatial Management, Maria CurieSkłodowska University, Lublin, Poland, andrzej.swieca@umcs.pl

\section{Introduction}

Water and matter circulation, distinguished by high temporal variability and considerable spatial variability, determines the modern development of the natural environment of the temperate climate zone. The character, range, and functioning of the circulation depend on the properties of the natural environment, including among others: land relief, hydro-climatic conditions (particularly the course and rate of precipitation and variability of temperatures), lithology of surface formations, land use structure, and human activity (Kostrze- wski, Szpikowski 2003). The determination of the processes of water circulation and fluvial transport in relation to the variability of environmental conditions is one of the most important aspects of the identification of the rules of functioning of geoecosystems (Gregory and Walling 1973, Kostrzewski et al. 1994, Krzemień 1999, Kostrzewski, Szpikowski 2003). The geoecosystem of a river catchment is the most convenient spatial unit for the determination of water and matter circulation.

The Roztocze part of the Wieprz River catchment constitutes an important part in the water management system of the entire catchment. 
The area of the catchment above Zwierzyniec, constituting 3.9\% of the area of the Wieprz River catchment, provides $6 \%$ of fluvial discharge. It is distinguished by the low level of environment degradation, expressed in a low value of the complex pollution coefficient (Świeca 1998, Świeca, Kociuba 2007). In such conditions, the type and amount of transported river load can reflect the current geomorphological processes (Gregory, Walling 1973). The study on river load could therefore be conducted in reference to Cholley's concept of a denudational system. According to the concept, transport in the river channel is referred to the catchment as the basic spatial unit (Kostrzewski 1993), and the amount of discharged material is treated as the index of the area's morphological activity (Świeca 1998).

The objective of the study was to present the spatial variability of the dynamics of fluvial processes in the Roztocze part of the Wieprz River catchment, as well as the relations between the quantitative indices of fluvial transport and hydro-climatic and geological conditions.

\section{Methods}

The spatial and temporal dynamics of selected processes of water circulation and fluvial transport were analysed in direct relation to the assessment of the variability of the geological and hydro-climatic conditions of the upper Wieprz River catchment. The study on the complex and co-dependent processes of water and matter circulation in relation to the spatial diversity of the geographic environment of the upper Wieprz River catchment required observation of hydrometeorological phenomena. Out of four analysed water gauge/hydrometric profiles, the main one (closing the upper Wieprz River catchment) was located in Zwirzyniec (permanent water gauge station of IMGW-BIP), and three (closing the subcatchments) in the tributaries: the Kryniczanka (in Dominikanówka), Jacynka (in Kaczórki), and Świerszcz Rivers (in Sochy). The obtained hydrometric data include results of daily water level and discharge rate measurements in Zwierzyniec, and weekly measurements in the tributaries. The meteorological conditions were analysed based on mean daily air temperatures and daily precipitation totals from the meteorological station of IMGW-BIP in Tomaszów Lubelski, located in the direct vicinity of the study area, approximately $36 \mathrm{~km} \mathrm{SE}$ of Zwierzyniec.

The measurements of fluvial transport rate in the upper Wieprz River catchment were performed in the hydrometric cross-section of IMGW-PIB in Zwierzyniec in intervals of two weeks (in the years 1989-1992) and one week (in the years 1998-2003). A total of 477 water samples were collected for the analyses of turbidity and determination of physical parameters, including 79 samples in the years 1989-1992, and 398 samples in the years 1998-2003. Samples for analyses of the concentration of suspention and dissolved material were collected by means of a bottle batimeter with a volume of $1 \mathrm{dm}^{3}$ more or less at half the depth of the current zone of the stream. The suspended load was calculated based on water turbidity measurements by means of the filter-weight method following Brański (1968), and water mineralisation by water specific electrical conductivity measurements with the application of a conductivity measure type MP-2 and OK. 102/1 by Redeliks. Water electrical conductivity (at a temperature of $25^{\circ} \mathrm{C}$ ) was converted to dissolved material concentration (Krawczyk 1996).

The estimation of the values of the analysed fluvial transport components was based on the regression between discharge and concentration. In the conducted analysis of coefficients of determination for 5 applied regression models, the highest coefficients were obtained for the quadratic polynomial regression model. It was used for the determination of daily loads of mineralisation and turbidity (Świeca 1998, Świeca, Kociuba 2004). After statistical analysis, the collected data provided the basis for the assessment of the variability of fluvial transport in relation to the volume and character of fluvial discharge and geological conditions. The study applied the results of research conducted in the years 19891992 (Świeca 1998), 1998-2000 (Rodzik, Świeca 2001), and 2001-2003 (Kociuba et al. 2003, Świeca, Kociuba 2004). 


\section{Environmental conditions of fluvial transport in the upper Wieprz River catchment}

In geomorphological terms (Maruszczak 1972), the catchment of the upper Wieprz River above Zwierzyniec, with an area of $404.0 \mathrm{~km}^{2}$, is located in the Roztocze Tomaszowskie sub-region (Fig. 1).

The analysed part of Roztocze is distinguished by a considerable diversity of geological-geomorphological conditions. Late Cretaceous rocks are of importance in morphological terms. They are varied in lithostratigraphic terms, including gaizes and margle gaizes, opokas and margle opokas, and margles (Cieśliński et al. 1996, Maruszczak, Świeca 2004). Late Cretaceous rocks (particularly Maastricht) are locally covered by patches of Early Neogene rocks represented by Miocene limnic and marine formations - loamy, sandy, sandy-carbonate, and carbonate (Musiał 1987). Neogene rocks (Baden) are deposited under a discontinuous Quaternary sediment cover (aeolian sands and loesses).
The basic features of the relief are related to Laramian tectonics, and its secondary features are determined by the arrangement and lithological properties of surface rock outcrops (Maruszczak, Świeca 2004). The landscape of the catchment features plateaus cutting Upper Cretaceous and Early Neogene rocks: the upper one reaches 320$350 \mathrm{~m}$ a.s.l., and the lower one $300-330 \mathrm{~m}$ a.s.l. In the landscape of the southern watershed zone, inselbergs are observed. One of them - Wapielnia - reaches 386 m a.s.l.

The Wieprz River is the main river of the analysed part of Roztocze. Its length from the source to Zwierzyniec amounts to $44.1 \mathrm{~km}(13.6 \%$ of its total length). The source of the Wieprz River is located in a peatland area in the vicinity of the village of Wieprzów Tarnawacki at an altitude of $273.5 \mathrm{~m}$ a.s.l. The lowest point in the water gauge profile closing the catchment is located at an altitude of $219.2 \mathrm{~m}$ a.s.l. The mean inclination of river channel is $1.23 \%$. It is within the range of inclinations typical of upland rivers (1-3\%o).

Almost the entire analysed catchment (more than $85 \%$ of its area) is under various forms of na-

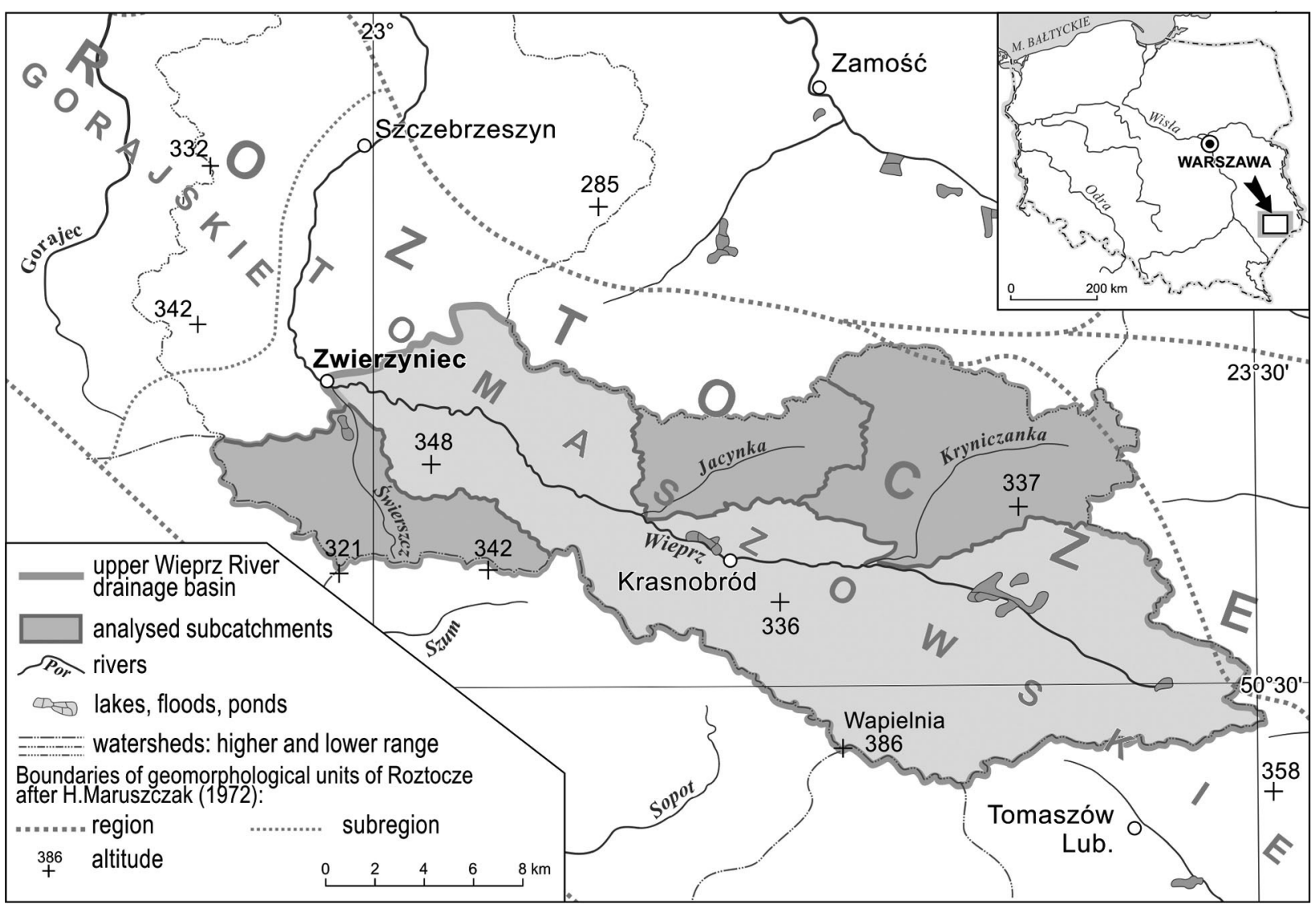

Fig. 1. Location of the upper Wieprz River drainage basin (with subcatchments) in relation to the gomorphological regions 
ture protection due to the low level of its anthropogenic transformation, and high environmental values. The catchment is distinguished by relatively high forest cover $(42.1 \%$ of the catchment area), and relatively low contribution of agricultural land (51.4\%) (Świeca et al. 2004).

\section{Hydro-climatic conditions in the study periods}

The outflow differences in the hydrometric profiles suggest the domination of nival-precipitation fluvial regime in the upper part of the Wieprz River catchment, with a slight prevalence of supply and runoff in the cold half year. The assessment of the catchment's hydrological conditions emphasises the regulating role of the bedrock in the development of fluvial runoff. The contribution of groundwater supply in the total fluvial runoff amounts to 83\% (Michalczyk 2004). Hydro-climatic conditions are largely respon- sible for the character and course of the fluvial transport processes in this river catchment. They determine their occurrence and intensity. The field research in periods 1989-1992, 1998-2000, and 2001-2003 was conducted in conditions considerably differing from mean multiannual values in hydro-climatic terms (Fig. 2; Table 1).

In terms of temperatures, the period 19891992 was considerably warmer, and in terms of precipitation - similar to the mean multiannual value. The mean annual temperature in Zwierzyniec was higher by $1.0^{\circ} \mathrm{C}$ than the multiannual. The mean annual precipitation total was lower by only $1.6 \%$ than the multiannual (Table 1). Years 1998-2000 were warmer and considerably more humid than the mean annual values. The mean annual temperature in Zwierzyniec was higher than the multiannual by $0.6^{\circ} \mathrm{C}$ (Table 1 ). The mean annual precipitation total in the years 1998-2000 was higher than the multiannual by 24\%. In terms of temperatures, years 2001-2003 were warmer, with a lower mean precipitation

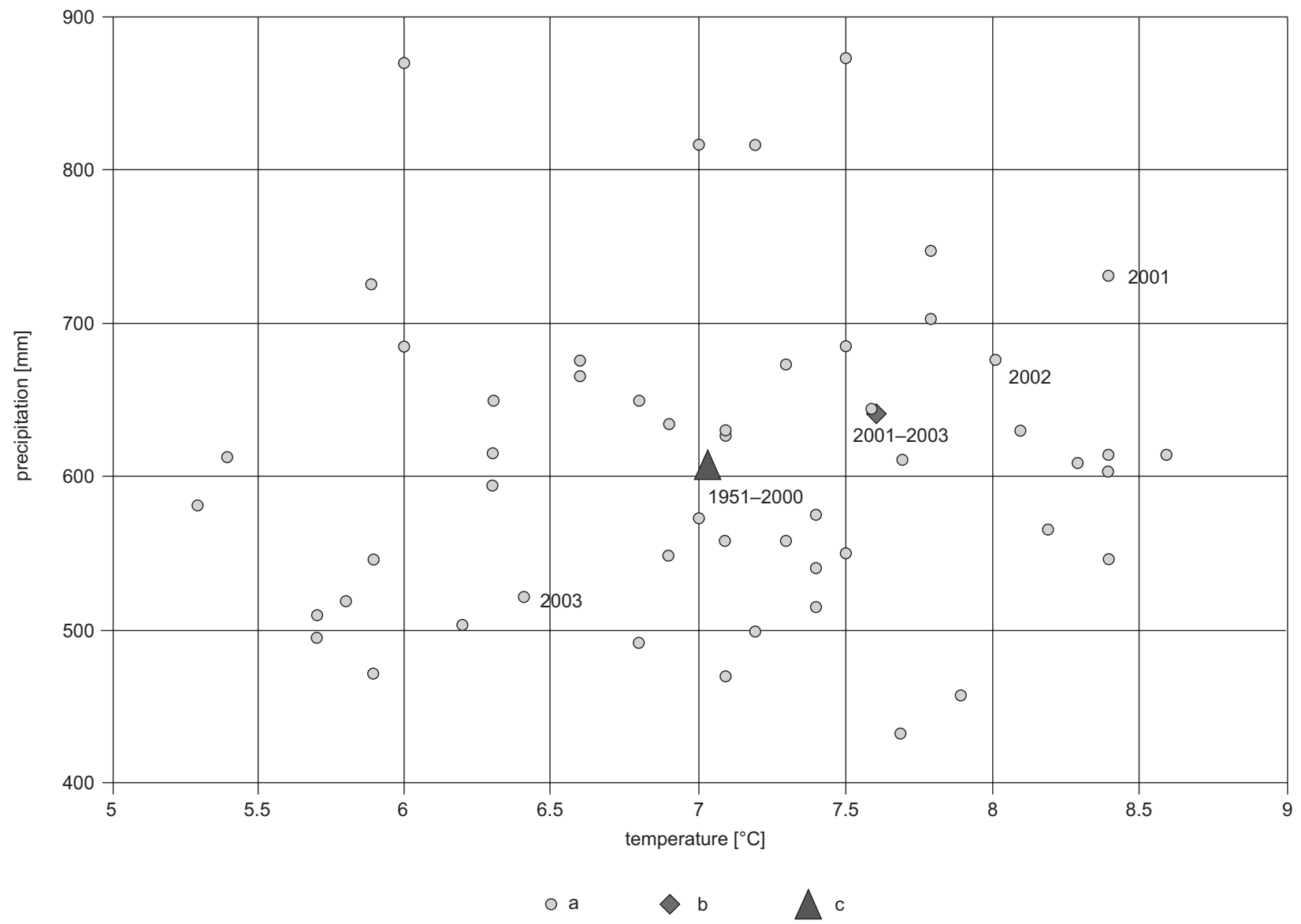

Fig. 2. Hydrological years 2001, 2002, and 2003 in the diagram of annual precipitation totals (mm) and mean air temperature $\left({ }^{\circ} \mathrm{C}\right)$ in consecutive years 1951-2003 in Tomaszów Lubelski [a]; additionally the mean from the period 2001-2003 [b] and multiannual mean from the period 1951-2000 [c] 
Table 1. Hydro-climatic indices of solution and suspension outflow in the years 1989-1992, 1998-2000, and 2001-2003 in relation to the multiannual 1951-2000 in the water gauge cross-section in Zwierzyniec

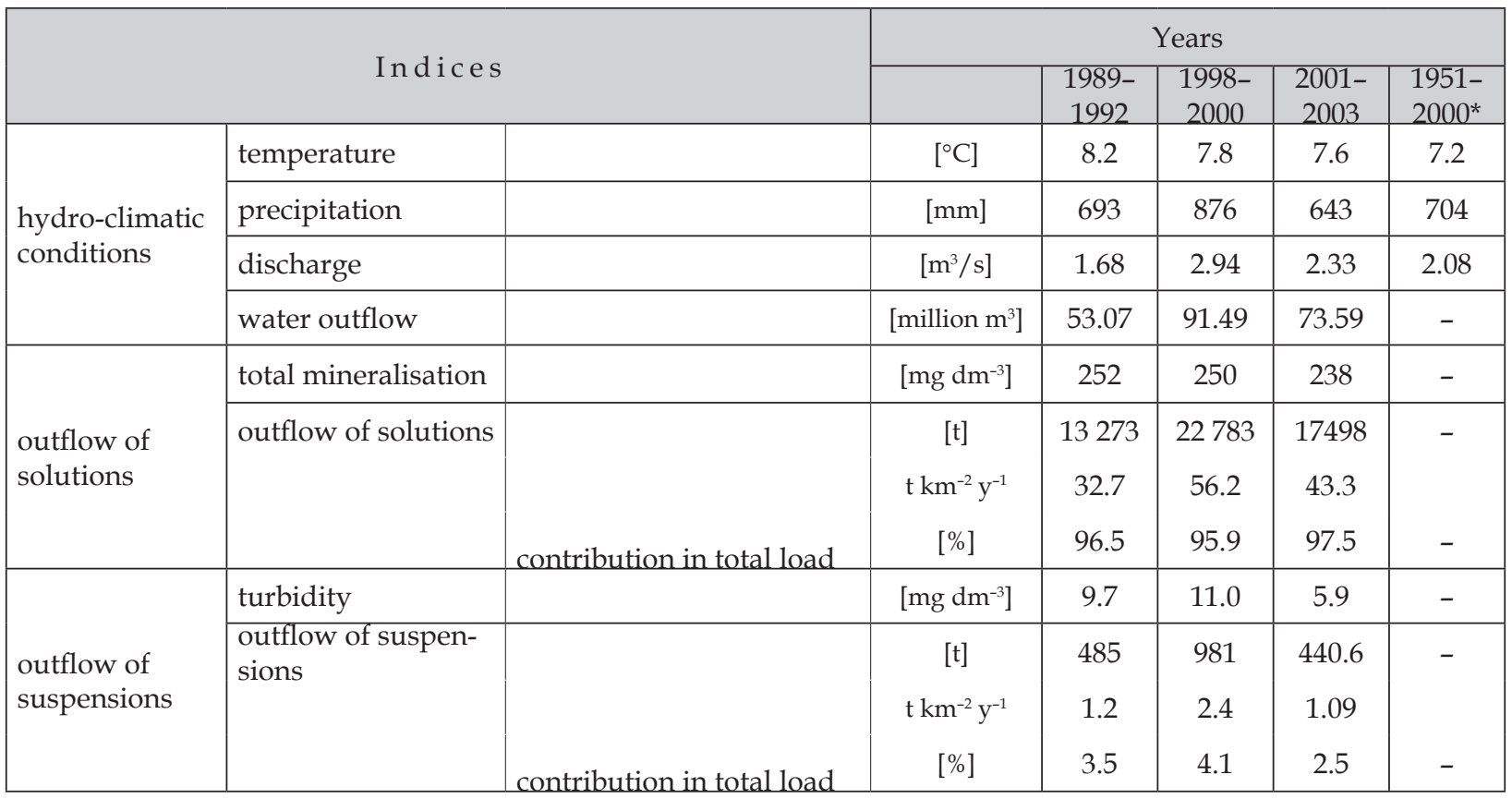

*temperature data for the multiannual 1951-1980.

The meteorological conditions was characterized based on mean daily air temperatures and daily precipitation totals from the meteorological station of IMGW-BIP in Tomaszów Lubelski.

total (Table 1). The mean annual temperature in Zwierzyniec was higher than the multiannual by $0.4^{\circ} \mathrm{C}$. The mean annual precipitation total was lower than the mean multiannual by $8.7 \%$. Based on the analysis of the temperature and precipitation conditions, the study periods can be respectively described as: warm and moderately humid in the years 1989-1992; exceptionally humid and moderately warm in the years 1998-2000; and moderately warm and moderately dry in the years 2001-2003.

Discharges of the Wieprz River in Zwierzyniec developed accordingly to the temperature and precipitation conditions. Mean annual values in the study periods were considerably varied, amounting to $1.68 \mathrm{~m}^{3} \mathrm{~s}^{-1}$ (1989-1992), $2.94 \mathrm{~m}^{3}$ $\mathrm{s}^{-1}$ (1998-2000), and $2.33 \mathrm{~m}^{3} \mathrm{~s}^{-1}$ (2001-2003). These values corresponded to the specific runoff of 4.1, 7.3 , and 5.8 , respectively at a mean annual of 5.1 $\mathrm{dm}^{3} \mathrm{~s}^{-1} \mathrm{~km}^{-2}$. The mean annual discharge in Zwierzyniec in the years 1998-1992 was lower than the multiannual by $19.2 \%$, and in the years 1998 2000 and 2000-2003, higher than the multiannual by 41.3 and $12.0 \%$, respectively (Table 1 ).

In the three discussed study periods, the mean monthly, seasonal, and annual discharges usually showed high variability in relation to the cor- responding values from the years 1951-2000. In the period 1989-1992, in particular years, mean annual discharges changed inconsiderably, and were usually lower than the mean multiannual values. In the remaining two periods, i.e. 19982000 and 2001-2003, annual discharges were usually higher.

\section{Concentration of dissolved material and dynamics of transport of solutions}

In the Roztocze part of the Wieprz River catchment, water physical parameters are particularly determined by geological conditions (Świeca 1998). In the upper Wieprz River in Zwierzyniec, relatively low variability of total mineralisation indices was recorded: from 228 to $265 \mathrm{mg} \mathrm{dm}^{-3}$ (mostly between 241 and $260 \mathrm{mg} \mathrm{dm}^{-3}$ ). The mean annual index showed a slight variability from 238 to $252 \mathrm{mg} \mathrm{dm}^{-3}$ (Table 1).

Among the conditions controlling physical and chemical properties of waters, the hydrological conditions are considered as the most important (Gregory, Walling 1973; Kostrzewski et al. 1994). A significant correlation was determined between total mineralisation $\left(C_{d}\right)$ and discharge 
(Q) $C_{d}=f(Q)$. In the analysed periods (1989-1992, 1998-2000, and 2001-2003), the highest coefficients of correlation ( $r$ from 0.508 to 0.620 ) were obtained for the quadratic polynomial regression model $\left(C_{d}=a Q^{2}+b Q+c\right)$, represented by a parabola. For the study periods the arms of the parabola are directed downwards. The course of the function suggests an increase in the concentration of dissolved material along with discharge until a certain threshold value. After exceeding the threshold value, the concentration decreases. At low discharges, relatively low concentration of dissolved material is related to the prevalence of groundwater supply and leaching of the underground catchment. Along with an increase in discharge, total mineralisation also increases. In Zwierzyniec, a discharge of $2 \mathrm{~m}^{3} \mathrm{~s}^{-1}$ constitutes the threshold value. After its exceeding, with growing discharge and contribution of surface flow, the concentration decreases. This may be related to higher dilution of solutions caused by water flowing through strongly leached nearsurface soil layers.

In the waters of the upper Wieprz River, the quadratic polynomial regression models of the correlation between total mineralisation and discharge were used for the determination of mineralisation for everyday discharges. Based on this, the daily, monthly, and annual load and transport of solutions were calculated. The volume of outflow of solutions was determined to be dependent on the volume of fluvial discharges. This is a proportionate correlation with relatively high coefficients of correlation ( $r$ from 0.906 to 0.935 ).

In the upper Wieprz River, the transported material was dominated by solutions. Their contribution varied from approximately $96.5 \%$ in the years $1998-2000$ to approximately $97.5 \%$ in the years 2001-2003 (Table 1). In Zwierzyniec, in the cross-section closing the studied part of the catchment, the amount of transported solutions particularly reflected the environmental conditions. In the years 1989-1992, the river transported approximately 13,300 tonnes of solutions annually. In the years 1998-2000 and 2001-2003, the values amounted to 22,783 and 17,498 tonnes, respectively. It should be emphasised that the study on fluvial transport in the years 1989-1992 was conducted at considerably lower, and in the years 1998-2003 at considerably higher discharges than mean multiannual values.

\section{Concentration of suspended material and dynamics of transport of suspensions}

In comparison with dissolved material, transport of suspensions is considerably more varied. The content of suspensions in fluvial waters is so variable - irrespective of the discharges themselves - that even daily measurements do not ensure accurate results.

In the hydrometric cross-section on the Wieprz River in Zwierzyniec, turbidity indices in the study periods varied from 0.1 to $24.3 \mathrm{mg} \mathrm{m}^{-3}$ (in the years 1989-1992), from 0.3 to $77.5 \mathrm{mg} \mathrm{m}^{-3}$ (in the years 1998-2000), and from 0.7 to $24.1 \mathrm{mg}$ $\mathrm{m}^{-3}$ (in the years 2001-2003). Mean annual values in the three study periods varied from 5.9 to $11.0 \mathrm{mg} \mathrm{m}^{-3}$ (Table 1).

The determined regression model between concentration of suspended material and water discharge with the application of the quadratic function (polynomial function of the second degree) suggests a very weak relationship, often at an insignificant level with very low coefficients of correlation ( $r$ from 0.092 to 0.256). A much stronger correlation with water discharge was determined for suspension load ( $r$ from 0.377 to 0.676).

In reference to the results of research on fluvial transport, it should be emphasised that the catchment of the upper Wieprz River is distinguished by a relatively low concentration of suspensions in fluvial transport (Świeca 1998, Rodzik, Świeca 2001, Kociuba et al. 2003, Świeca, Kociuba 2004, Stępniewski, Rodzik 2008). In the three study periods, transported suspensions constituted from 2.5 to $4.1 \%$ of annual fluvial discharge (Table 1 ).

In the conditions of low human influence, a strong relationship between transport of suspended load and discharge values was observed. In the years 1989-1992, the Wieprz River discharged an average of approximately 485 tonnes of suspensions annually. In the years 1998-2000, at an almost double increase of discharge in the river, transport of suspensions was also doubled to a value of 981 tonnes. Lower discharges in the years 2001-2003 caused a decrease in the weight of transported suspensions to 441 tonnes. The mean annual unitary outflow amounted to 1.2, 2.4 , and $1.1 \mathrm{t} \mathrm{km}^{-2} \mathrm{y}^{-1}$, respectively. 


\section{Diversity of geoecosystems in the upper part of the Wieprz River catchment}

Partial catchments of three tributaries of the Wieprz River were selected for the determination of the diversity of the natural conditions and degree of anthropopressure in the upper part of the Wieprz River catchment, namely those of the Kryniczanka $\left(66.7 \mathrm{~km}^{2}\right)$, Jacynka $\left(30.2 \mathrm{~km}^{2}\right)$, and Świerszcz Rivers (45.4 km²) (Fig. 1; Table 2).

In geological terms, the Kryniczanka River catchment stands out among the Lower Maastricht marl opokas and margles, covered by loesses and loess-like formations $(80.0 \%$ of the catchment). The catchment is distinguished by the lowest extreme denivelation, the lowest relief ratio, and the highest catchment elongation index. The valley shape coefficient and the edge sinuosity index are the same as in the Świerszcz River catchment (Table 2). The catchment is relatively strongly affected by economic activity. Agricultural land constitutes approximately $83 \%$ of the catchment area (including $67 \%$ of cultivated land), with the highest contribution of meadows and pastures $(17 \%)$. The mean discharge of the Kryniczanka River in its mouth section amounts to approximately $250 \mathrm{dm}^{3} \mathrm{~s}^{-1}$. The waters of the Kryniczanka River show a relatively high level of mineralisation $\left(270 \mathrm{mg} \mathrm{dm}^{-3}\right)$.

In relation to the Kryniczanka River catchment, the Jacynka River catchment is distinguished by its geological conditions with the prevalence of loesses and loess-like formations and sands, and deluvial loams. Due to this, index values describing relief features (extreme denivelation and relief ratio) are higher and respectively lower valley shape coefficient (the lower the index value, the deeper the river valley is indented). Here, the catchment elongation index reaches the lowest value among all of the three analysed catchments (Table 2). It has the highest contribution of agricultural land (67\%, including $57 \%$ of cultivated fields), and the lowest forest cover $(26 \%)$. The mean discharge of the Jacynka River in its mouth section is approximately five times lower than for the Kryniczanka River, and amounts to approximately $50 \mathrm{dm}^{3} \mathrm{~s}^{-1}$. The waters of the Jacynka River are less mineralised (186 mg $\left.\mathrm{dm}^{-3}\right)$.

The Świerszcz River catchment is distinguished by the highest diversity of geological conditions (Lower Maastricht gaizes and margle gaizes; Upper Baden detritic and algal reef limestones; deluvial, aeolian, and alluvial fan sands), and consequently orographic conditions (highest extreme denivelation and relief ratio) (Table 2). The catchment has the highest forest cover $(61 \%)$ and the lowest contribution of agricultural land (35\%, including $34 \%$ of cultivated fields). The mean discharge of the Świerszcz River is almost 2.5 times lower than that of the Kryniczanka River, and amounts to approximately $100 \mathrm{dm}^{3} \mathrm{~s}^{-1}$. The waters of the Świerszcz River are the least mineralised $\left(177 \mathrm{mg} \mathrm{dm}^{-3}\right)$.

In the analysed partial catchments, the volume of transported solutions and suspensions reflects the natural conditions and degree of anthropopressure. In the analysed catchments, the material transported in the river beds is dominated by solutions. Their contribution varies from approximately 80 to $97 \%$. The Kryniczanka River, the largest tributary of the upper Wieprz River, transports approximately 1,950 tonnes of dissolved material annually. The value for the Świerszcz River is approximately 950 tonnes, and for the Jacynka River - approximately 250 tonnes. The unitary solution outflow indices for the catchments amount to 29,20 , and $8 \mathrm{t} \mathrm{km}^{-2} \mathrm{y}^{-1}$.

Suspensions constitute from approximately 3.5 to $20.5 \%$ of the transported material. Low contributions of suspensions (approximately 3.5$4.0 \%$ of the total load) are recorded in the catchments of the Świerszcz (forested catchment) and Kryniczanka Rivers (extensive meadows in the valley bottom). The contribution is considerably higher (approximately 20.5\%) in the Jacynka River catchment, distinguished by high expansion of loess formations, lower forest cover, and the highest contribution of cultivated fields.

\section{Final remarks}

The results obtained based on the regression between discharge and concentration of the analysed river load components reflect the estimated values. Following Stach (2002, 2008), the method of load estimation adopted in the study does not consider the strong temporal autocorrelation of concentrations and discharges. The results of the study of fluvial transport in the upper Wieprz River catchment document the response of 
Table 2. Indices of solution and suspension outflow in the years 2001-2003 in catchments of the tributaries of

the upper Wieprz River in relation to hydrological descriptions and geological-morphometric parameters

\begin{tabular}{|c|c|c|c|}
\hline & Kryniczanka River & Jacynka River & Świerszcz River \\
\hline \multicolumn{4}{|c|}{ Geological descriptions (based on: Musiał 1987; Cieśliński et al. 1996) } \\
\hline $\begin{array}{l}\text { Maastricht rocks } \\
{[\% \text { of the catchment area] }}\end{array}$ & \multirow{3}{*}{$\begin{array}{c}\text { Lower Maastricht margle } \\
\text { opokas and margles; } \\
\text { loesses and loess-like } \\
\text { formations } \\
80.0\end{array}$} & $\begin{array}{l}\text { Lower Maastricht margle } \\
\text { opokas and margless } \\
9.0\end{array}$ & $\begin{array}{l}\text { Lower Maastricht gaizes } \\
\text { and margle gaizes }\end{array}$ \\
\hline $\begin{array}{l}\text { Miocene rocks } \\
{[\% \text { of the catchment area] }}\end{array}$ & & & $\begin{array}{l}\text { Upper Baden detritic and } \\
\text { algal reef limestones }\end{array}$ \\
\hline $\begin{array}{l}\text { loesses and loess-like formations } \\
\text { [\% of the catchment area] }\end{array}$ & & 48.1 & \\
\hline $\begin{array}{l}\text { sands and deluvial loams } \\
\text { [\% of the catchment area] }\end{array}$ & & 27.3 & \\
\hline $\begin{array}{l}\text { sandy formations } \\
\text { [\% of the catchment area] }\end{array}$ & & & $\begin{array}{c}\text { deluvial, aeolian, and allu- } \\
\text { vial fan sands } 47.0\end{array}$ \\
\hline \multicolumn{4}{|c|}{ Morphometric descriptions } \\
\hline extreme denivelation $[\mathrm{m}]$ & 72.7 & 79.0 & 111.8 \\
\hline $\begin{array}{l}\text { relief ratio } \\
(\mathrm{Rh}=\mathrm{H} / \mathrm{L}, \text { Schumm 1954; Strahl- } \\
\text { er 1954) }\end{array}$ & 0.009 & 0.014 & 0.020 \\
\hline $\begin{array}{l}\text { catchment elongation ratio }(\operatorname{Re}= \\
2(\mathrm{~A} / \Pi)^{0.5} / \mathrm{L} \text {, Schumm 1954) }\end{array}$ & 0.97 & 0.72 & 0.73 \\
\hline $\begin{array}{l}\text { valley shape coefficient }(\mathrm{Vf}= \\
2 \mathrm{Vfw} /[(\text { Eld-Esc })+(\text { Erd-Esc })] \\
\text { Bull, Mc Fadden } 1977)\end{array}$ & $\begin{array}{c}0.4-0.9 \\
1.0-3.2 \\
3.7-22.9\end{array}$ & $\begin{array}{l}0.6-0.9 \\
1.0-3.3\end{array}$ & $\begin{array}{c}0.4-0.9 \\
1.0-3.2 \\
3.7-22.9\end{array}$ \\
\hline $\begin{array}{l}\text { edge sinuosity index ( } \mathrm{S}=\mathrm{Lmf} / \mathrm{Ls} \text {, } \\
\text { Bull 1977) }\end{array}$ & $1.1-1.4$ & $1.0-1.1$ & $1.0-1.1$ \\
\hline \multicolumn{4}{|c|}{ Hydrological descriptions } \\
\hline discharge $\left[\mathrm{m}^{3} \mathrm{~s}^{-1}\right]$ & 0.21 & 0.04 & 0.16 \\
\hline $\begin{array}{l}\text { water outflow } \\
\left.\text { [million } \mathrm{m}^{3}\right]\end{array}$ & 6.71 & 1.19 & 5.05 \\
\hline \multicolumn{4}{|c|}{ Solution outflow indices } \\
\hline total mineralisation $\left[\mathrm{mg} \mathrm{dm}^{-3}\right]$ & 270 & 186 & 177 \\
\hline outflow of solutions [t] & 1934.0 & 234.4 & 932.5 \\
\hline Unit outflow of solutions $\left[\mathrm{t} \mathrm{km}^{-2} \mathrm{y}^{-1}\right]$ & 28.56 & 7.71 & 20.32 \\
\hline contribution in total load [\%] & 96.0 & 79.5 & 96.7 \\
\hline \multicolumn{4}{|c|}{ Suspension outflow indices } \\
\hline turbidity $\left[\mathrm{mg} \mathrm{dm}^{-3}\right]$ & 8.1 & 22.2 & 5.9 \\
\hline outflow of suspension [t] & 81.3 & 60.4 & 32.2 \\
\hline $\begin{array}{l}\text { Unit outflow of suspension } \\
{\left[\mathrm{t} \mathrm{km}^{-2} \mathrm{y}^{-1}\right]}\end{array}$ & 1.20 & 1.98 & 0.70 \\
\hline contribution in total load [\%] & 4.0 & 20.5 & 3.3 \\
\hline
\end{tabular}

$\mathrm{H}$ - Difference of extreme elevations; L - Maximum catchment length; A - Total area of catchment;

Vfw - Valley floor width, Eld - Elevation (m a.s.l.) of the left valley divide, Erd - Elevation ( $\mathrm{m}$ a.s.1.) of the right valley divide, Esc - Elevation (m a.s.1.) of the valley floor.

Lmf - Length of the mountain front along the foot of the mountain, Ls - Straight line length of the mountain.

an upland river to changes in hydrological conditions. Periods 1989-1992 and 1998-2000 can be considered extreme in hydrological terms.

The four-year period from 1989 to 1992 was distinguished by low water stages. Mean annual discharges were lower than multiannual values by $19 \%$. On the average, the Wieprz River discharged approximately 13300 tonnes of solutions and 485 tonnes of suspensions annually from the catchment with an area of $404 \mathrm{~km}^{2}$. Unitary indi- ces amounted to 32.7 and $1.2 \mathrm{t} \mathrm{km}^{-2} \mathrm{y}^{-1}$, respectively. In the years 1998-2000, in the conditions of high water stages, mean annual discharges were higher than the multiannual values by $41 \%$. The Wieprz River discharged an average of approximately 22800 tonnes of solutions and 981 tonnes of suspensions annually. Along with an almost triple increase in discharges in relation to the dry years 1989-1992, also the solution (56.2 $\mathrm{t} \mathrm{km}^{-2}$ $\left.\mathrm{y}^{-1}\right)$ and suspension transport index $\left(2.4 \mathrm{t} \mathrm{km}^{-2}\right.$ 
$\left.\mathrm{y}^{-1}\right)$ almost doubled. In the years 2001-2003, in the conditions of varied water stages, discharges were higher than the multiannual values by $12 \%$. In such conditions, the Wieprz River discharged an average of approximately 17,500 tonnes of solutions and 441 tonnes of suspensions annual$\mathrm{ly}$, and the unitary indices reached $43.3 \mathrm{t} \mathrm{km}^{-2} \mathrm{y}^{-1}$ and $1.1 \mathrm{t} \mathrm{km}^{-2} \mathrm{y}^{-1}$, respectively.

The lithological diversity of surface formations and their use have a considerable effect on the intensity of geochemical processes in the analysed catchments. This is reflected in the values of fluvial transport indices. No significant correlation was determined between relief diversity expressed in the analysed morphometric indices and the values of fluvial transport indices.

\section{References}

Brański J., 1968. Oznaczenie ilości unosin metodą wagową bezpośrednio przy użyciu sączków (Determination of suspended load by direct weight method using filters). Prace PIHM 94: 13-21.

Cieśliński S., Kubica B., Rzechowski J., 1996. Mapa geologiczna Polski. 1:200 000. Tomaszów Lubelski, Dołhobyczów. B - Mapa bez utworów czwartorzędowych (Geological Map of Poland 1:200 000. Tomaszów Lubelski, Dołhobyczów. B - Map without Quaternary sediments). Wydawnictwo Kartograficzne Polskiej Agencji Ekologicznej S.A. Warszawa.

Bull W.B., 1977. Tectonic geomorphology of the Mojave Desert. U.S. Geological Survey Contract Report 14-08-001-G394./Office of Earthquakes, Volcanoes and Engineering, Menlo Park, California: 188 pp.

Bull W.B., McFadden L.D., 1977. Tectonic geomorphology north and south of the Garlock fault, California. In: Doehring D.O. (ed.), Geomorphology in Arid Regions. Proceedings of the 8th Annual Geomorphology Symposium. State University of New York at Binghampton, 9: 115-138.

Gregory K.J., Walling D.E., 1973. Drainage basin form and process. Arnold, London: 1-456.

Kociuba W., Świeca A., Brzezińska-Wójcik T., 2003. Dynamika transportu fluwialnego w zlewni górnego Wieprza w skrajnych warunkach hydrologicznych (The dynamics of fluvial transport in the upper Wieprz catchment in extreme hydrological conditions). In: Śmigielska M., Słodczyk J. (ed.), Geograficzne aspekty globalizacji i integracji europejskiej. Opole: 57-63.

Kostrzewski A., 1993. Geoekosystem obszarów nizinnych. Koncepcja metodologiczna (The geoecosystem of lowland areas: A methodological conception). In: Kostrzewski A. (ed.), Geoekosystem obszarów nizinnych. Zakład Narodowy im. Ossolińskich, Wrocław, Wrocław, Komitet Naukowy przy Prezydium PAN „Człowiek i Środowisko", Zeszyty Naukowe 6: 11-17.

Kostrzewski A., Szpikowski J. (eds), 2003. Funkcjonowanie geosystemów zlewni rzecznych (The functioning of geosystems of river catchments). Bogucki Wydawnictwo Naukowe, Poznań.

Kostrzewski A., Mazurek M., Zwoliński Zb., 1994. Dynamika transportu fluwialnego górnej Parsęty jako odbicie funkcjonowania systemu zlewni (Dynamics of fluvial transport of the upper Parsęta River as a response of the catchment). Wydawnictwo Naukowe: Poznań.

Krawczyk E., 1996. Manual for karst water analysis. Intern. Journal of Speleology, Handbook 1 - Physical Speleology.

Krzemień K. (ed.), 1999. River channels - pattern, structure and dynamics. Prace Geograficzne, Instytut Geografii UJ 104.

Maruszczak H., Świeca A., 2004. Charakterystyka środowiska przyrodniczego zlewni górnego Wieprza. Charakterystyka geologiczna i geomorfologiczna (Natural features of the upper Wieprz catchment. Geological and geomorphological characteristics). In: Świeca A. (ed.), Przyrodnicze uwarunkowania dynamiki obiegu wody i natężenia transportu fluwialnego w zlewni górnego Wieprza. Wydawnictwo UMCS, Lublin: 23-32.

Michalczyk Z., 2004: Charakterystyka stosunków wodnych (Characteristics of water relations). In: Świeca A. (ed.), Przyrodnicze uwarunkowania dynamiki obiegu wody i natężenia transportu fluwialnego w zlewni górnego Wieprza. Wydawnictwo UMCS, Lublin: 50-64.

Musiał T., 1987. Miocen Roztocza (Polska południowo-wschodnia) (Miocene of Roztocze (south-eastern Poland). (in Polish, English summary). Biuletyn Geologiczny Uniwersytetu Warszawskiego 31: 5-140.

Rodzik J., Świeca A., 2001. Sezonowa zmienność wskaźników odpływu i transportu rzecznego górnego Wieprza w „mokrych" latach 1998-2000 (Seasonal variability of indicators of discharge and river transport of the upper Wieprz in "wet" years 1998-2000). In: Piotrowska I., Zwoliński Z. (ed.), Funkcjonowanie geosystemów w zróżnicowanych warunkach klimatycznych. Monitoring, ochrona, edukacja. Streszczenia Konferencji Naukowej, 19-20 X 2001, Poznań: 124-125.

Schumm S.A., 1954. Evolution of drainage systems and slopes in badlands at Perth Amboy, New Jersey. Geology Department, Columbia University, ONR Project Technical Report 8: 389-420.

Stach A., 2002. Geostatistical identification of solute transport mechanism in rivers (in Polish with English summary). Przegląd Naukowy Inżynierii i Kształtowania Środowiska 11(2): 130-143.

Stach A., 2008. A different basis for choosing rivers chemical load estimation methodology. Quaestiones Geographicae 27A/2: 85-93.

Stępniewski K., Rodzik J., 2008. Discharge and fluvial transport in two catchments of the Roztocze region (SE Poland). Quaestiones Geographicae 27A/2, 95-103.

Strahler A.N., 1954. Statistical analysis in geomorphic research. Journal of Geology 62: 1-25.

Świeca A., 1998. Wpływ czynników antropogenicznych na rzeczny odpływ roztworów i zawiesin na międzyrzeczu Wisły i Bugu (Anthropogenic effects on river discharge of solutes and suspended sediment in the Vistula and Bug interfluve). Rozprawy habilitacyjne LXI, UMCS, Lublin.

Świeca A., Kociuba W., 2004. Dynamika przepływu i transportu fluwialnego $\mathrm{w}$ zlewniach cząstkowych górnej części dorzecza Wieprza w latach 2001-2003. Charakter, zróżnicowanie przestrzenne i dynamika zmian rzecznego transportu (The dynamics of the flow and fluvial 
transport in the sub-catchments of the upper part of the Wieprz basin in 2001-2003. Nature, spatial diversity and dynamics of river transport). In: Świeca A. (ed.), Przyrodnicze uwarunkowania dynamiki obiegu wody i natężenia transportu fluwialnego w zlewni górnego Wieprza. Wydawnictwo UMCS, Lublin: 160-200.

Świeca A., Kociuba W., 2007. Environmental determinants of the character and intensity of fluvial transport in the upland areas of central eastern Poland. Quaestiones Geographicae 26A: 67-75.

Świeca A., Jóźwik M.J., Kociuba W., 2004. Teren badań (Study area). In: Świeca A. (ed.), Przyrodnicze uwarunkowania dynamiki obiegu wody i natężenia transportu fluwialnego w zlewni górnego Wieprza. Wydawnictwo UMCS, Lublin: 10-16. 